\title{
Conceptual Knowledge, Experiences, and Sources of Information Secondary School Students Have About Owls
}

\author{
M. Said Doğru* \\ Department of Medical Services and Techniques, Arac Rafet Vergili Vocational School of Higher Education, Kastamonu University, Kastamonu, \\ Turkey
}

*Corresponding Author: msaid.dogru@yahoo.com

\section{ABSTRACT}

This study examined the level of knowledge the students had about owls by means of drawings and written answers. In the interviews, the students in the lower grades were found to have more limited information and less biological literacy than the ones in the upper grades. The aim was to determine students' knowledge, experience, and sources of information about owls, and then to determine how useful they were by comparing information obtained from drawings and written answers to previous research conducted with students. A total of 878 students in the sixth and seventh grades in Turkey participated in the research. The students were familiar with certain characteristics of owls. The drawings provided clearer information about body parts and proportions, while the specific habitats, behaviors, and feeding of owls were expressed in more detail in the written responses. The students without any experience with owls were inadequate in reporting information about owls. When the frequencies of responses in the general concept categories about owls were compared, it was found that the use of drawings and written answers was equally beneficial for upper and lower grade students. It would be better to determine the views and sources of information of secondary school students through drawings and written answers to assess whether they have understood the concepts related to science subjects.

KEY WORDS: Secondary school students; conceptual information about owls; drawings and written answers of students; their experiences

\section{INTRODUCTION}

B irdLife International (2022) identifies 14 owl (strigiformes) species. These species are Common Barn-owl, Northern Hawk-owl, Eurasian Pygmy-owl, Little owl, Boreal Owl, Eurasian Scops-owl, Pallid Scops-owl, Northern Long-eared Owl, Short-eared Owl, Tawny Owl, Ural Owl, Snowy Owl, Eurasian Eagle-owl, and Brown Fish-owl (BirdLife International, 2022). With its climate, topographic features and protected areas, Turkey is home to thousands of endemic species that are unique to these regions in the world and is the last area where many species can survive. This century has seen a decline especially in the bird species. There are several endangered species of owls. Eight different species of owls exist in our country. Among these, the Eurasian eagleowl (Bubo-bubo), the tawny owl (Strix aluco), and the brown fish-owl bird (ketupa zeylonensis) are in danger of extinction. The long-eared owl (Asio atus) and the barn owl (Tyto alba) are in extreme danger (Başlar and Şahin, 1993). With the rapid increase in population in the world in the $21^{\text {st }}$ century and the increase in human needs, rapid, and unconscious consumption of various sources such as air and water, spreading waste around the environment, and distorted urbanization cause many problems, including the disruption of the natural balance. When the natural balance is disrupted, serious environmental problems emerge (Akınoğlu and Sarı, 2009). These problems can be solved with environmental education. The aim of environmental education is to create knowledge, attitudes, behaviors, and awareness about the environment in society. In order to ensure the continuity of the ecosystem, it is necessary to learn about animals, their distinctive features, understand that they are elements of a natural heritage (Yazıc1, 2019).

With the gain of "Analyzes the effects of unconscious consumption of resources on all living creatures, " as a part of the Production, Distribution and Consumption learning area in the sixth grade Social Studies Curriculum (MEB, 2018a) and the gain of "Takes care of a plant or animal and reports the development process," as a part of the Living Creatures and Life learning area in the seventh grade Science Curriculum, students are taught about their environment, being sensitive toward to environment, the importance of life and endangered species (MEB, 2018b). For this reason, when the curricula are not integrated with nature and living world, students can grow up to become individuals who lack environmental consciousness such as perception of nature, comprehending the richness and variety of nature and caring about living things in nature (Kahyaoğlu and Yetişir, 2015). Students spend most of their time at school. In modern urban life, we do not often encounter wild animal species. Generally speaking, individuals are not involved any kind of interaction with animals in daily life, except cats, dogs, birds, and some insect species. Many of us have only seen wild or endemic animal species on TV shows, magazines, or internet (Prokop et al., 2007). Therefore, 
students have limited knowledge of endemic owl species that are part of our country's ecosystem. In that regard, Hummel et al. (2015) investigated the general attitude of students in their study of birds in Turkey and reported their participants were positive. In addition, Torkar and Bajd (2006) stated in their study that the endangered bird species should be protected. In this study, students' perceptions of owls were tried to be revealed with drawings and written responses.

Drawings are useful for investigating learners' understanding in different contexts and about a variety of phenomena (Dempster and Stears, 2014). Drawings are often used to obtain an idea of children's conceptions. Doing so takes for granted an unambiguous relation between conceptions and their representations in drawings (Ehrlén, 2009). In the drawings approach, learners are asked to present their mental models as 'drawings' rather than as verbal or written explanations (Dempster and Stears, 2014). One underused technique is that of eliciting ideas through children's drawings (Hayes et al., 1994). Drawings are also a useful alternative form of expression for children who have difficulty expressing their thoughts verbally (Rennie and Jarvis, 1995). While a large amount of research exists concerning the use of drawings to probe learners' understanding of biological phenomena (Bahar et al., 2008; Garcia-Barros et al., 2011; Manokore and Reiss, 2003; Reiss and Tunnicliffe, 2001), the number of Turkish studies is limited. There are many studies in the literature examining students' knowledge of birds (Tunnicliffe, 2011; Hummel et al., 2015; Kubiatko and Balatova, 2017; Gnidovec and Torkar, 2019; Torkar et al., 2019). However, there is not much research on owls, an endemic species.

The aim of this research was to determine students' opinions about owls through drawings and written responses. Research questions are as follows:

1. What do sixth and seventh grade students know about owls?

2. What information about owls can be collected through Drawings and written responses?

3. From which source did the students gain information about owls?

\section{METHODS}

\section{Research Model}

The aim of this research was to determine students' schematic models about owls, this was a hermeneutical phenomenology research study. Phenomenological research tries to understand individuals' experiences on a concept or phenomenon (Creswell, 2007). Phenomenology focuses on phenomena which we are aware of but do not extensively and thoroughly understand (Yıldırım and Şimşek, 2016). The general purpose of phenomenological research is to collect data from the experiences of participants (Fraenkel and Wallen, 2008). Hermeneutical phenomenological research is research that obtains data from both written and visual sources (Creswell, 2007). This study was shaped as hermeneutical phenomenology research as data were obtained from both written and visual responses of students.

\section{Sample}

The research was conducted with 878 students from ten schools in Turkey. The study consisted of 878 students attending sixth grade $(n=450)$ and seventh grade $(n=428)$. The ages of the students ranged between 11 and 12 and the average age was 11.5. Before the research was carried out, permission was obtained from the administrations of the schools where the research would be conducted, and in some schools, the questionnaire form was evaluated by the schools' own ethics committees, and their approvals were obtained. Detailed information about the research was given to the participant candidates on the first page of the questionnaire and it was emphasized that the decision to participate or not to participate was taken into consideration voluntarily. As the study group, convenience sampling, which is one of the purposive sampling methods, was preferred. Although there are no rules in the sample size in qualitative research, the validity and confidence of the research depends on the wealth of information obtained (Patton, 2014).

\section{Data Collection Tool and Data Collection}

In this study, an open-ended interview form was prepared by the researchers to examine students' thoughts about owls in depth with drawings and written responses. The structured interview allows comparison by determining the parallels and the differences between the information the participants provide (Yıldırım and Şimşek, 2016). The students were asked to draw an owl on a sheet of paper and name the body parts of the owl in their drawings. The students were then asked to identify an owl for someone who had never seen or heard an owl. Ten students were randomly selected for interviews from among students who completed the drawings and written responses. Interviews were conducted with open-ended questions about appearance of owls, students' attitudes toward owls and symbolic representations of owls (Torkar and Bajd, 2006; Torkar et al., 2019; Gnidovec and Torkar, 2019).

\section{Data Analysis}

Content analysis technique was used in the analysis and interpretation of the data obtained as a result of the research. In content analysis, qualitative data reduction and interpretation efforts are aimed to determine the basic consistencies and meanings by considering qualitative data (Patton, 2014). In this context, by analyzing the data in depth, the written explanations of the students about owls were categorized and percentage and frequency values of the categories and subcategories were calculated. Mann-Whitney and Kruskal-Wallis tests were used to analyze the differences between students' drawings and written answers and different variables (gender, class, and experiences with living owls). The coding was done by the researchers. In terms of the ethics of the research, the students were given a code with the help of numbers. While analyzing the data, the students were coded. A series of datadriven categories were created by reading the responses of 
the students to the questions. The coding was matched by the students' explanation of the sources of information about owls. The analyses were examined by a second researcher to ensure the consistency of the coding. In addition, the data are presented in Tables 1 and 2 as shown in the findings section. Torkar et al. (2019) and Gnidovec and Torkar (2019) were used while creating the tables.

\section{FINDINGS}

Analyzing students' drawings can help with understanding the mental models of the real world around them in depth. Therefore, students' thoughts about owls were collected with the help of drawing and written responses. While $28.9 \%$ of the students drew an owl in color, the majority drew a black and white owl. $10.2 \%$ of the students outlined a bird that did not resemble an owl (see for example Figure 1).

These drawings mostly show the basic features of birds such as the head, body, wings, legs, and beak. $82.4 \%$ of the students' drawings depicted the physical characteristics of owls such as large eyes, round face discs, and tufts (Figure 2).

About $2.9 \%$ of the students were able to depict the characteristics of a species that resembled a real owl (Figure 3).

The three figures above show the characteristics of the owl drawings of the students. $6^{\text {th }}$ and $7^{\text {th }}$ grade students drew drawings of owls, showing some of their physical characteristics, such as a round head, big eyes, and tufts, which

\begin{tabular}{|c|c|c|c|c|c|c|}
\hline \multirow[t]{2}{*}{ Sub-classifications } & \multicolumn{2}{|c|}{$6^{\text {th }}$ grade } & \multicolumn{2}{|c|}{$7^{\text {th }}$ grade } & \multicolumn{2}{|c|}{ Total } \\
\hline & $f$ & $\mathrm{f} \%$ & $f$ & $\mathrm{f} \%$ & $f$ & $\mathrm{f} \%$ \\
\hline Physical properties & 2865 & 57.8 & 2974 & 60.0 & 5839 & 58.9 \\
\hline Body & 396 & 88.0 & 389 & 86.4 & 785 & 89.4 \\
\hline Legs & 390 & 86.6 & 402 & 89.3 & 792 & 90.2 \\
\hline head & 375 & 83.3 & 410 & 91.1 & 785 & 89.4 \\
\hline Ears & 273 & 60.6 & 330 & 73.3 & 603 & 68.6 \\
\hline Feather & 96 & 21.3 & 120 & 26.6 & 216 & 24.6 \\
\hline Wings & 360 & 80 & 345 & 76.6 & 705 & 80.2 \\
\hline Color & 105 & 23.3 & 126 & 28.0 & 231 & 26.3 \\
\hline Tail & 30 & 6.6 & 54 & 12.0 & 84 & 9.5 \\
\hline Claws & 63 & 14 & 72 & 16.0 & 135 & 30.0 \\
\hline Eyes & 420 & 93.3 & 361 & 80.2 & 781 & 88.9 \\
\hline Beak & 357 & 79.3 & 365 & 81.1 & 712 & 81.1 \\
\hline Owls' natural environments & 134 & 29.7 & 204 & 48.0 & 338 & 38.9 \\
\hline Rocky Region & 48 & 10.6 & 54 & 12.7 & 102 & 13.6 \\
\hline Forest and Trees & 90 & 20 & 126 & 29.6 & 216 & 24.6 \\
\hline Fed & 9 & 2.0 & 3 & 0.7 & 12 & 1.3 \\
\hline Multiple drawings & 20 & 4.4 & 12 & 2.8 & 32 & 3.6 \\
\hline Other features & 8 & 1.7 & 7 & 1.6 & 15 & 1.6 \\
\hline Movements of Owls & 533 & 60.7 & 710 & 80.8 & 1243 & 70.7 \\
\hline Walking & 76 & 16.8 & 128 & 30.1 & 204 & 23.4 \\
\hline Flying & 274 & 60.8 & 309 & 35.1 & 583 & 47.9 \\
\hline Standing in a tree & 183 & 40.6 & 273 & 64.2 & 456 & 52.4 \\
\hline
\end{tabular}

they usually associate with owls. Table 1 shows the categories and subcategories of owl drawings.

As shown in Table 1, in the drawings $89.4 \%$ of the students drew the head of the owl, $89.4 \%$ drew the body, $88.9 \%$ drew the eyes, $90.2 \%$ drew the legs, $81.1 \%$ drew the beaks, $80.2 \%$ drew the wings, $68.6 \%$ drew the ears, $24.6 \%$ drew the feathers, $26.3 \%$ showed the colors, $30.0 \%$ drew the paws, and $9.5 \%$ drew the tails. Furthermore, a student drew a drawing of an owl with a rabbit. Five students painted owls at night. About $38.9 \%$ of

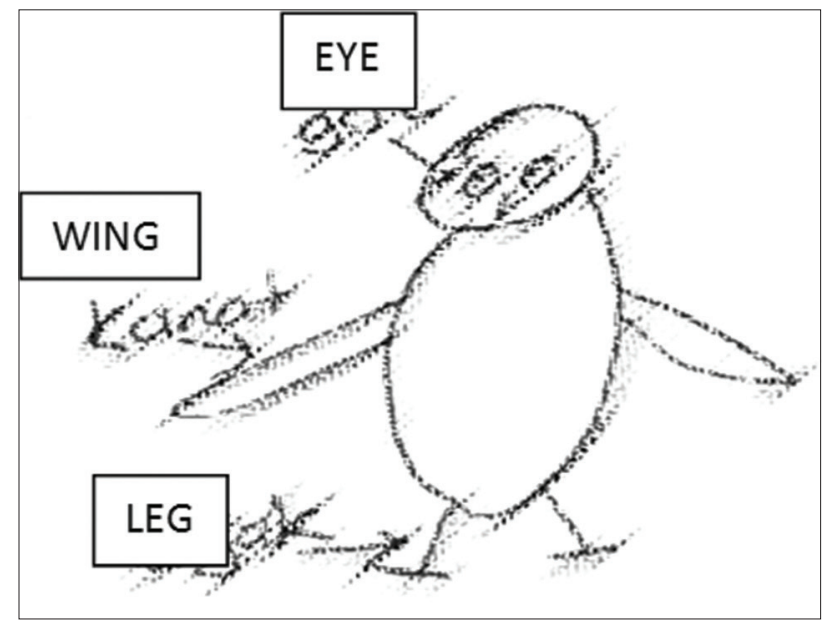

Figure 1: Sample drawings of owls by student

Table 2: Categories and subcategories of students' written responses about owls

\begin{tabular}{|c|c|c|c|c|c|c|}
\hline \multirow[t]{2}{*}{ Sub-classifications } & \multicolumn{2}{|c|}{$6^{\text {th }}$ grade } & \multicolumn{2}{|c|}{$7^{\text {th }}$ grade } & \multicolumn{2}{|c|}{ Total } \\
\hline & $f$ & $f \%$ & $f$ & $f \%$ & $f$ & $f \%$ \\
\hline Physical properties & 914 & 25.9 & 1619 & 38.5 & 2638 & 36.4 \\
\hline Body & 39 & 8.6 & 66 & 15.5 & 105 & 12.0 \\
\hline Legs & 143 & 32.7 & 192 & 45.1 & 335 & 68.4 \\
\hline head & 156 & 34.6 & 158 & 37.1 & 314 & 35.4 \\
\hline Ears & 99 & 22.0 & 139 & 32.7 & 196 & 22.4 \\
\hline Feather & 48 & 10.6 & 62 & 14.5 & 110 & 12.5 \\
\hline Wings & 147 & 32.6 & 186 & 43.7 & 333 & 38.6 \\
\hline Color & 96 & 21.3 & 154 & 36.2 & 250 & 29.2 \\
\hline Tail & 21 & 4.6 & 39 & 9.1 & 60 & 6.8 \\
\hline Claws & 46 & 10.2 & 124 & 29.1 & 170 & 14.8 \\
\hline Beak & 105 & 23.3 & 197 & 46.3 & 302 & 35.3 \\
\hline Eyes & 119 & 25.7 & 344 & 80.9 & 463 & 52.8 \\
\hline Other features & 172 & 38.2 & 129 & 30.3 & 301 & 34.2 \\
\hline Owls' natural environments & 192 & 42.6 & 224 & 52.7 & 416 & 47.3 \\
\hline Rocky Region & 17 & 0.4 & 21 & 4.9 & 23 & 2.7 \\
\hline Crowing & 126 & 28.0 & 150 & 35.2 & 276 & 31.6 \\
\hline Listening & 64 & 14.2 & 55 & 12.9 & 119 & 13.5 \\
\hline Head turns & 75 & 16.6 & 155 & 36.4 & 230 & 26.5 \\
\hline Fed & 163 & 36.2 & 122 & 28.7 & 285 & 32.4 \\
\hline Forest and trees & 200 & 44.4 & 280 & 62.2 & 480 & 53.5 \\
\hline Other & 67 & 14.8 & 12 & 2.8 & 79 & 8.8 \\
\hline Movements of owls & 782 & 89.0 & 429 & 95.3 & 1201 & 92.1 \\
\hline Walking & 210 & 46.6 & 236 & 55.5 & 446 & 51.0 \\
\hline Flying & 324 & 72.0 & 361 & 84.9 & 685 & 78.4 \\
\hline Night moving & 412 & 91.5 & 450 & 51.2 & 862 & 71.3 \\
\hline
\end{tabular}




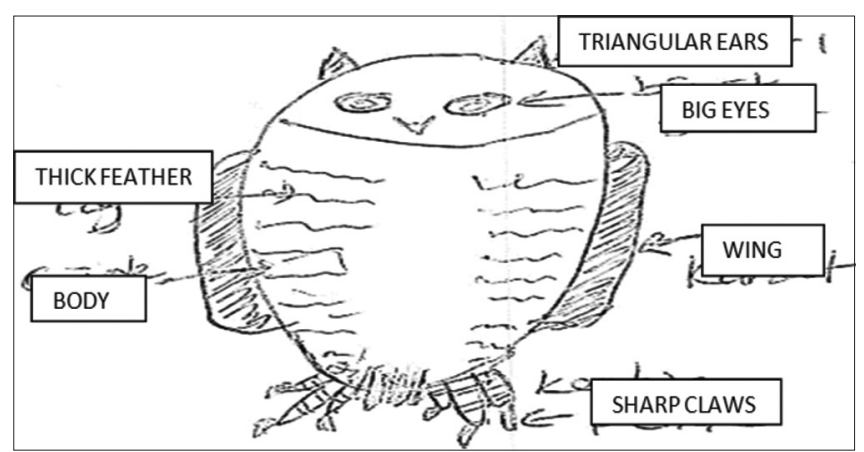

Figure 2: Sample drawings of owls by student

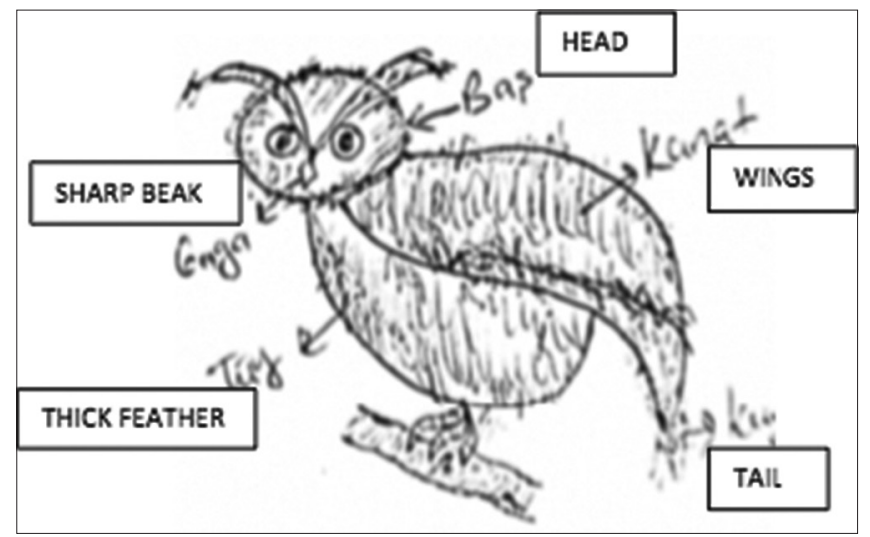

Figure 3: Sample drawings of owls by student

the students painted owls in their natural environment. These natural environments consist of trees and rocky areas in forests. In the drawings, $47.9 \%$ of the students drew an owl flying, $52.4 \%$ drew one perched on a tree, and $23.4 \%$ drew an owl walking. About $79.7 \%$ of the students drew a drawing of an owl outside of the natural environment of the owls. Some of the knowledge students have about owls was collected with written responses. Information on these written responses is shown in Table 2.

Table 2 shows the categories and subcategories of the students' written responses about owls. The physical characteristics of owls constitute $50 \%$ of the answers given to the written responses asked to $6^{\text {th }}$ and $7^{\text {th }}$ grade students who participated in our research. Among the answers given to the physical characteristics, the eyes of the owls were $52.8 \%$, wings $38.6 \%$, legs $68.4 \%$, heads $35.4 \%$, beaks $35.3 \%$, colors $29.2 \%$, ears $22.4 \%$, claws $14.8 \%$, feathers $12.5 \%$, body $12.0 \%$, and tail $6.8 \%$. About $49.9 \%$ of the students stated that owls had characteristic movements. In the answers given by the students, $47.3 \%$ was about the habitat of owls. About $53.5 \%$ of the students stated that owls live in forests and on tree branches and only a small percentage said they live in rocky areas. Addition, there were very few comments about owls being birds of prey and their brooding. The students also talked about certain features of the owl, such as good vision, hearing-listening and rotating ability, ears, wings, tail and heads. About $92.38 \%$ of the students said owls are nocturnal, $78.4 \%$ said owls fly,
$51.0 \%$ said owls walk, $32.4 \%$ said owls feed, $27.1 \%$ said owls sing, $31.6 \%$ said owls can rotate their heads, and $13.5 \%$ said owls can hear very well. On the other hand, while the students talked about the feeding patterns of owls, they said that the animals most hunted by owls were rabbits, snakes and insects. There was no statistically significant difference between the sixth and seventh grade students, or girls and boys, regarding the number of categories determined by drawings and written responses. However, according to the written responses $(t(878)=3,741, \rho=0.034)$ and drawings $(t(878)=2,378$, $\rho=0.038)$, there was a statistically significant difference between the students with and without knowledge about owls. About $78.4 \%$ of the students stated that they encountered owls in their surroundings, $28.2 \%$ said that they saw them at a zoo, and $12.8 \%$ stated that they had never seen an owl before. In addition, it was found in our study that the students who had seen owls before drew more accurate drawings of owls than the ones who had never seen one before. A few of them mistakenly thought that the Turkish word "owl" referred to a sparrow (Little Owl; Turkish).

In this part of our study, ten students were interviewed to determine how sixth and seventh grade students obtained information about owls. Students were asked "Where did you first see an owl? Please explain," and the following responses were collected. The student in the example above stated that he/she saw an owl directly in its natural habitat for the first time.

I saw one on a nature hike with my family. It was the weekend, and it was getting darker outside. Then my father showed me the owl perching on a tree. It was just sitting there. I thought it would be bigger, but it was smaller than I'd thought. It was gray. When I asked my father if it would attack us, he told me that it could be dangerous for other animals, not for us.

The student in the example above stated that he/she saw an owl directly in its natural habitat for the first time.

We have a garden outside the city. We go there on weekends. I've seen owls in our garden many times. One constantly perches on top of the big tree under the gazebo.

In this example, the student stated that he/she saw owls many times in their garden located outside the city. Evidently, natural environments, national parks, and forests outside the cities play an important role in learning about natural life.

I've never seen an owl in nature, unfortunately. But I can tell you that I saw one at the zoo. It had brown feather. It was a short-eared owl if I'm not mistaken.

I've seen boards with information about owls and some pictures at the zoo. I remember touching a mummified owl.

In the examples above, one student stated that he/she saw an owl in the zoo, and the other said that he/she had obtained information about owls from informational literature at the zoo. This shows that zoos are a very effective source of information about animals. 
Students also stated that they had learnt about owls in school, heard about them in fairy tales, stories, songs, games, saw them as toys, in movies, documentaries, etc. Below are some examples of students' views.

I actually saw one on a friend's shirt and there are pencil cups with owls on them and also toy owls. It's actually possible to see owls in many places.

I've seen owls in a documentary. It told about how they fly, how they feed, and even the sounds they make.

I wanted to learn more about owls when I saw them for the first time and I thought they were interesting. I knew that I had to learn more about those birds. I started looking them up on the Internet and in various books. According to the information I learned, owls live in stony areas and in ruins. They might also be seen at those places.

I wanted to learn more about owls when I saw them for the first time, and I thought they were interesting. I knew that I had to learn more about those birds. I started looking them up on the Internet and in various books. According to the information I learned, owls live in stony areas and in ruins. They might also be seen at those places.

In the examples above, one student stated that owls also live in rocky areas, tropical forests, caves, wells, and ruins.

Students were also asked if they were afraid of owls. Some students explained that owls are very dangerous and symbolize death. One student explained his/her thoughts influenced by the popular movie Legend of the Guardians: The Owls of Ga'Hoole:

I saw them in the movie Legend of the Guardians: The Owls of Ga'Hoole. A young owl was trying to be freed of the other owls. The movie scared me. Because until the end of the movie, owls looked like scary and deadly animals.

A picture of an owl was shown to the students and they were asked whether it looked different from other birds. It was observed that the students had misinformation especially about the feathers in the ear areas of owls.

The body part that I find interesting in owls is their ears. Especially the tufts on the tips of their ears, which I don't think every owl has. I saw more than one species of owls in the last film, but not every owl had tufts on their ears.

\section{DISCUSSION AND CONCLUSION}

It is seen from students' drawings and written answers that most of them know what an owl looks like. Drawings and written explanations of owls are external representations of mental models that children acquire over time (Cummings, 1989; Halmatov et al., 2012). Based on students' drawings and written answers, it could be concluded that participants have some, though not much, knowledge on the appearance, behavior, diet, and habitat of owls. Tunnicliffe (2011) stated that primary school students provided mental models on pigeons based on their knowledge of themselves or other birds that they knew. The researcher also stated that some students' opinions and concepts such as all birds eating worms could be reinforced using cartoons and popular stories. However, this study could not confirm that students stated their opinions on owls based on their general knowledge of birds. The fact that students' opinions on owls could not be confirmed by their general knowledge of birds may be due to the fact owls are a well-known and remarkable bird group because of their frequent symbolization and appearances in children's literature. In conclusion, it could be said that students were aware of some of the specific features distinguishing owls from other birds (i.e., big head and eyes, feathers).

Many drawings and written answers, as was the case in the spotted owl example, include explanations on owls' habitats (trees and forest) to encourage the fact that they should be protected (Tempel et al., 2017). Students have only mentioned trees, forests, or rocks as owls' habitats. Owls' habitats such as those of the spotted owl living in anthropogenic environments were not explained or described by students.

Some misconceptions were found in students' written answers and drawings. For example, some thought that the word "owl" belonged to the little owl species. This misunderstanding could be related to a popular children's story of a little owl and a true sparrow. Similarly, Torkar et al. (2019) stated that many primary school students had misconceptions about owls, that they thought the little owl species was female and that they learned it from songs. Further studies could be conducted to analyze the reasons behind these misconceptions in a more detailed fashion.

According to Kellert (1985), the truth-based perception of students between the age of 10-13 on animals develops quickly and they state their ethical concerns and ecological praises on animals and the natural environment between the ages of 13-16. In this study, participants aged between 10 and 15 had some truth-based knowledge and perception of animals, and some students reported the protection status of these bird species. However, it was found out that important differences in students' written answers were that they only mentioned the fact that owls had a very well-developed hearing as well as describing their habitat.

In our study, students expressed their opinions on the appearance, behavior, and ecology of an owl. They stated that they regarded owls as the symbol of wisdom and death by establishing a relationship with feathers and ears found in the bird's head. This could be related to a belief regarding owls in Turkish society. The fact that some beliefs are suggesting that death will arise from the house when an owl perches on its chimney and that an owl perching on the roof and hooting will bring bad news could be an explanation for students' perceptions (Kaman, 2015).

Any mode of external representation of biological ideas, concepts, or facts is a special way of representing objects 
in the real life. Visualization is important, especially in biology teaching because objects that are analyzed are often too complex biological systems. Modes of representation, as the most abstract model of the human language, were described as the continuation of increasing abstraction (Niebert and Gropengiesser, 2015). As suggested by Prokop and Fančovičová (2006), a combination of students' drawings and written answers could provide more reliable information on students' opinions. This study evaluated the knowledge of students aged between 10 and 15 on owls by analyzing two modes of external representation: Owl drawings as a realistic mode and written explanations of owls as an abstract model. Findings demonstrate that students' written answers provide more information on their opinions about owls, especially on the special behavior patterns, diet, and habitat status of owls. However, some information on owls' body parts and ratios, as well as their lives, could be described more easily and clearly with drawings. We plan to conduct the same research again with students in the $8^{\text {th }}$ and $10^{\text {th }}$ grades in our next study. The main aim of the next study will be to investigate the benefits of collecting students' knowledge from written answers and drawings and to compare the findings with this study. We believe that students will provide more information in their drawing compared to this study because their ability to provide written information might increase as their learning levels and awareness increase. The previous studies also support this finding (Özsoy, 2012).

\section{REFERENCES}

Akınoğlu, O., \& Sarı, A. (2009). Environmental education in primary school curriculum. Marmara University Atatürk Education Faculty Journal of Educational Sciences, 30(30), 5-29.

Bahar, M., Ozel, M., Prokop, P., \& Usak, M. (2008). Science student teachers' ideas of the heart. Journal of Baltic Science Education, 7, 78-85.

Başlar, S., \& Şahin, N. (1993). Ecological balance and extinct values. Environmental Journal, 9, 15-20.

BirdLife International. (2022). European Red List of Birds. Available from: http://datazone.birdlife.org/info/euroredlist

Creswell, J.W. (2007). Qualitative Inquiry and Research Design. $2^{\text {nd }}$ ed. London: SAGE.

Cummings, J.A. (1989). Projective drawings. In: Knoff, H.M. (Ed.), The Assessment of Child and Adolescent Personality. Marquette: The Guilford. pp. 199-239.

Dempster, E., \& Stears, M. (2014). An analysis of children's drawings of what they think is inside their bodies: A South African regional study. Journal of Biological Education, 48(2), 71-79.

Ehrlén, K. (2009). Drawings as representations of children's conceptions. International Journal of Science Education, 31(1), 41-57.

Fraenkel, J.R., \& Wallen, N.E. (2008). How to Design and Evaluate Research in Education. $7^{\text {th }}$ ed. New York: McGraw-Hill.

Garcia-Barros, S., Martı'nez-Losada, C., \& Garrido, M. (2011). What do children aged four to seven know about the digestive system and the respiratory system of the human being and of other animals? International Journal of Science Education, 33, 2095-2122.

Gnidovec, T., \& Torkar, G. (2019). Primary school students' conceptions about owls, experiences with owls and their sources of information. Journal of Baltic Science Education, 18(2), 254-263.

Halmatov, M., Sarıçam, H., \& Halmatov, S. (2012). Research on 6 ages children' drawing environment picture and perception on the environment concept while taking pre-school education according to different variables. International Social Science Education of Journal, 2(1), 30-44.

Hayes, D., Symington, D., \& Martin, M. (1994) Drawing during science activity in the primary school. International Journal of Science Education, 16, 265-277.

Hummel, E., Ozel, M., Jerez, W.M., Usak, M., Prokop, P., \& Randler, C. (2015). Interest in birds and its relationship with attitudes and myths: A cross-cultural study in countries with different levels of economic development. Educational Sciences: Theory and Practice, 15(1), 285-296.

Kahyaoğlu, M., \& Yetişir, M. İ. (2015). A phenomenographic study on the concept of nature and alienation of children from nature. Education and Science, 40(182), 159-170.

Kaman, S.G. (2015). Baykuş Kelimesi ve Baykuşla İlgili İnançlar Üzerine [On the Owl Word and Owl-Related Beliefs]. Turkish Studies, 10(8), $1137-1154$.

Kellert, S.R. (1985). Attitudes toward animals: Age-related development among children. The Journal of Environmental Education, 16, 29-39.

Kubiatko, M., \& Balatova, K. (2017). The lower secondary school pupils' attitudes toward and knowledge about water birds. Eurasia Journal of Mathematics, Science and Technology Education, 13, 1161-1176.

Manokore, V., \& Reiss, M. (2003). Pupils' drawings of what is inside themselves: A case study in Zimbabwe. Zimbabwe Journal of Educational Research, 115, 28-43.

MEB. (2018a). Social Studies Curriculum (Primary and Secondary 4, 5, 6 and 7 Grades). Ministry of National Education. Available from: http:// mufredat.meb.gov.tr/ProgramDetay.aspx?PID=354

MEB. (2018b). Science Course Curriculum (Primary and Middle School 3, 4, 5, 6, 7 and 8 Grades). Ministry of National Education. Available from: http://mufredat.meb.gov.tr/ProgramDetay.aspx?PID=354

Niebert, K., \& Gropengiesser, H. (2015). Understanding Starts in the Mesocosm: Conceptual metaphor as a framework for external representations in science teaching. International Journal of Science Education, 37(5-6), 903-933.

Özsoy, S. (2012). Investigation elementary school students' perceptions about environment through their drawings. Educational Administration: Theory and Practice, 12(2), 1717-1739.

Patton, M.Q. (2014). In: Bütün, M., Demir, S.B., (Eds.), Qualitative Research and Evaluation Methods. Pegem Akademi.

Prokop, P., \& Fančovičová J. (2006). Students' ideas about the human body: Do they really draw what they know? Journal of Baltic Science Education, 2(10), 86-95.

Prokop, P., Prokop, M., Tunnicliffe, S.D., \& Diran, C. (2007). Children's ideas of animals' internal structures. Journal of Biological Education, 41(2), 62-67.

Reiss, M.J., \& Tunnicliffe, S.D. (2001). Students' understanding of human organs and organ systems. Research in Science Education, 31, 383-399.

Rennie, L.J., \& Jarvis, T. (1995). Children' s choice of drawings to communicate their ideas about technology. Research in Science Education, 25, 239-252.

Tempel, D.J., Gutiérrez, R.J., \& Peery, M.Z. (2017). Population distribution and trends of California spotted owls. In: Gutiérrez, R.J., Manley, P.N., Stine, P.A., (Eds.), The California Spotted Owl: Current State of Knowledge. General Technical Reports, PSW-GTR-254. U.S. Department of Agriculture, Forest Service, Pacific Southwest Research Station. pp. 75-107.

Torkar, G., \& Bajd, B. (2006). Trainee teachers' ideas about endangered birds. Journal of Biological Education, 41(1), 5-8.

Torkar, G., Gnidovec, T., Tunnicliffe, S.D., \& Tomažič, I. (2019). Assessing students' knowledge of owls from their drawings and written responses. Journal of Biological Education, 53(1), 54-62.

Tunnicliffe, S.D. (2011). Visualization of animals by children: How do they see birds? CEPS Journal, 1(4), 63-80.

Yazıc1, Ö. (2019). Investigation of the student views' on zoogeographical teaching in terms of animal protection awareness. International Journal of Geography and Geography Education, 40, 1-22.

Yıldırım, A., \& Şimşek, H. (2016). Qualitative Research Methods in the Social Sciences. $10^{\text {th }}$ ed. Turkey: Seçkin Yayınevi. 